\title{
PERAN PENDIDIKAN BERBASIS HIGHER ORDER THINKING SKILLS (HOTS) PADA TINGKAT SEKOLAH MENENGAH PERTAMA DI ERA SOCIETY 5.0 SEBAGAI PENENTU KEMAJUAN BANGSA INDONESIA
}

\author{
Ramadhan Prasetya Wibawa ${ }^{1)}$, Dinna Ririn Agustina ${ }^{2)}$ \\ Universitas PGRI Madiun \\ ramadhan@unipma.ac.id ${ }^{1)}$, dinnara28@gmail.com ${ }^{2)}$
}

\begin{abstract}
At the time of the Industrial Revolution now the Indonesian government program for equity, has been re-launched society 5.0. Society 5.0 is an era initiated by the Japanese government with the concept of a human-centered society and technology-based. The current era of global competition requires the existence of quality learning to provide facilities for students in developing skills, skills and abilities as capital to face challenges in global life. Therefore it is necessary to apply the HOTS learning system (Higher Order Thinking Skills. Higher Order Thinking Skills (HOTS) is a process of thinking students in higher cognitive levels developed from various concepts and cognitive methods and taxonomy of learning such as problem solving methods, taxonomy bloom, and taxonomy of learning, teaching, and assessment.The main goal of high order thinking skills is how to improve students 'critical thinking skills at a higher level. The results are by applying HOTS learning (Higher Order Thinking Skills students' ability to think critically at school the middle class is faster in accepting various types of information, creative thinking in solving a problem using the knowledge they have and making decisions in complex situations.
\end{abstract}

Keywords: HOTS; Junior high school; Era of Society 5.0

\begin{abstract}
Abstrak
Pada saat revolusi Industri sekarang ini program pemerintah Indonesia guna pemerataan, sudah diluncurkan kembali society 5.0. Society 5.0 merupakan era yang dicetuskan oleh pemerintah Jepang dengan konsep masyarakat yang berpusat pada manusia (human-centered) dan berbasis teknologi (technology based). Era baru ini menjadi tantangan dan peluang bagi masyarakat dan khususnya siswa untuk meningkatkan soft skill sehingga mampu meningkatkan kecakapan dan keterampilan untuk belajar dan belajar sehingga mampu menjadi modal untuk masa yang akan datang. Oleh sebab itu perlu menerapkan sistem pembelajaran HOTS (Higher Order Thinking Skills. Higher Order Thinking Skills (HOTS) merupakan suatu proses berpikir peserta didik dalam level kognitif yang lebih tinggi yang dikembangkan dari berbagai konsep dan metode kognitif dan taksonomi pembelajaran seperti metode problem solving, taksonomi bloom, dan taksonomi pembelajaran, pengajaran, dan penilaian. Tujuan utama dari HOTS adalah bagaimana meningkatkan kemampuan berpikir kritis peserta didik pada level yang lebih tinggi. Jenis penelitian ini adalah penelitian kualitatif dengan menggunakan metode deskriptif. Hasil penelitian ini didapat dari kajian beberapa literatur. Hasilnya dengan menerapkan pembelajaran HOTS kemampuan siswa untuk berpikir secara kritis pada sekolah menengah pertama lebih cepat dalam menerima berbagai informasi, berpikir kreatif dalam memecahkan suatu masalah menggunakan pengetahuan yang dimiliki serta membuat keputusan dalam situasi-situasi yang kompleks.
\end{abstract}

Kata Kunci: HOTS; Sekolah Menengah Pertama; Era Society 5.0 


\section{PENDAHULUAN}

Pendidikan sangat diperlukan pada diri setiap manusia. Banyak hal yang harus dikorbankan bagi seseorang untuk mendapatkan pendidikan yang layak. Dengan adanya gempuran globalisasi yang merajarela bahkan menguasai setiap lini kehidupan, pendidikan menjadi salah satu dasar pertahanan setiap orang untuk menghadapi berbagai dampak dari globalisasi tersebut. Manusia dengan kecanggihan otak untuk berpikir, masih perlu adanya pengawasan untuk menjadikan berbagai pikiran dari manusia terus berkembang sesuai dengan perkembangan zaman. Globalisasi sendiri membawa berbagai dampak bagi bangsa Indonesia. Dampak positif dan dampak negatif terus bermunculan disetiap persoalan globalisasi. Dengan adanya dampak yang ditimbulkan dari globalisasi, maka setiap orang perlu berpikir lebih kritis dan inovativ untuk menghadapi berbagai dampak yang ditimbulkan. Kemajuan globalisasi pada mulanya dimulai dengan adanya revolusi industri 4.0. Lifter dan Tschiener (2013) "prinsip dasar industri 4.0 adalah penggabungan mesin, alur kerja, dan sistem, dengan menerapkan jaringan cerdas di sepanjang rantai dan proses produksi untuk mengendalikan satu sama lain secara mandiri". Jaringan internet sudah berkembang sangat pesat disemua kalangan. Bahkan merambah ke kalangan pelajar tingkat menengah pertama. Saat revolusi Industri pada saat ini masih dikejar pemerintah Indonesia guna pemerataan, sudah diluncurkan kembali society 5.0. society 5.0 merupakan era yang dicetuskan oleh pemerintah Jepang. Konsep masyarakat yang berpusat pada manusia (humancentered) dan berbasis teknologi (technology based). Di dalam konsep "Society 5.0" ini, manusia akan berperan lebih besar dengan mentransformasi big data menjadi suatu kearifan baru yang pada akhirnya meningkatkan kemampuan manusia untuk membuka peluang-peluang bagi kemanusian demi tercapainya kehidupan bermakna. Dengan adanya konsep society 5.0, maka kecerdasan manusia akan tergantikan dengan kecanggihan robot. Hal ini dilakukan oleh pemerintah jepang karena populasi di jepang mengalami penurunan yang signifikan di setiap tahunnya, maka dari itu untuk mensiasati penurunan jumlah pendudukan yang semakin berkurang, pemerintah membuat bebagai robot canggih untuk memenuhi kebutuhan mereka. Di saat Indonesia masih mengejak pemerataan diera revolusi industri 4.0, Jepang sudah mulai mencanangkan era baru society 5.0. hal ini tentu saja menuntut setiap orang untuk berpikir lebih kritis lagi dibandingkan dengan sebelumnya. Salah satu sarana untuk mengembangkan sikat kristis pada diri seseorang melalui pembelajaran disekolah. Beberapa tahun kebelakang, pemerintah Indonesia sudah mengganti kurikulum pembelajran di Indonesia. Sariono (2013) mengemukakan bahwa "kurikulum merupakan landasan yang digunakan pendidik untuk membimbing peserta didiknya kearah tujuan pendidikan melalui akumulasi sejumlah pengetahuan, ketrampilan, dan sikap mental". Jika dulu, pemerintah lebih memusatkan kepada teacher center, maka di kurikulum terbaru, pemerintah lebih menekankan pada student center. Era persaingan global saat ini menuntut adanya suatu pembelajaran yang bermutu untuk memberikan fasilitas bagi anak didik dalam mengembangkan kecakapan, keterampilan dan kemampuan sebagai modal untuk menghadapi tantangan di kehidupan global. Maka dari itu mulai sekarang, pemerintah sudah menerapkan sistem pembelajaran HOTS. "Higher Order Thinking Skills (HOTS) merupakan suatu proses berpikir peserta didik dalam level kognitif yang lebih tinggi yang 
dikembangkan dari berbagai konsep dan metode kognitif dan taksonomi pembelajaran seperti metode problem solving, taksonomi bloom, dan taksonomi pembelajaran, pengajaran, dan penilaian" (Saputra, 2016). "HOTS adalah kemampuan berpikir yang mencakup pemikiran kritis, logis, reflektif, metakognitif, dan kreatif" (King, Goodson, \& Rohani, 1998). "Kemampuan berpikir tingkat tinggi terdiri dari pemikiran logis, pemikiran kritis dan kemampuan penalaran yang merupakan kemampuan dasar dalam kehidupan sehari-hari, terlepas dari prestasi akademisnya" (Marshall \& Horton, 2011). "HOTS bisa dikatakan berhasil apabila peserta didik terlibat dengan apa yang mereka ketahui dalam proses pembelajaran tersebut kemudian peserta didik mampu untuk membedakan ide atau gagasan secara jelas, berargumen dengan baik, mampu memecahkan masalah, mampu mengkonstruksi penjelasan, mampu berhipotesis dan memahami hal-hal kompleks menjadi lebih jelas, dimana kemampuan ini jelas memperlihatkan bagaimana peserta didik bernalar." Dengan adanya pendidikan yang berbasis HOTS pada pelajar tingkat menengah pertama, diharapkan mampu menjadikan mereka untuk lebih berpikir kritis tentang apa yang terjadi di dunia luar, sehingga mereka mampu untuk menghadapi era dimana terjadinya transisi antara revolusi industri 4.0 dengan era society 5.0 yang sudah berkembang di negara Jepang.

\section{METODE PENELITIAN}

Jenis penelitian ini adalah penelitian kualitatif. Rofi'udin (2003) mengatakan "penelitian kualitatif merupakan penelitian yang didasarkan pada data yang berupa katakata dalam mendeskripsikan objek-objek yang diteliti". Metode yang digunakan dalam penelitian ini adalah metode deskripsi. Ibnu, dkk. (2003, hlm. 46) menjelaskan bahwa "penelitian deskriptif bertujuan untuk mendeskripsikan (memaparkan) peristiwa yang terjadi pada masa kini". Hasil penelitian didapat dari hasil kajian beberapa literatur. Literatur yang digunakan, berkaitan dengan teori karya ilmiah, teori metode pembelajaran, dan HOTS. Literatur tersebut didapat dari beberapa buku teori dan jurnal nasional. Teori berkaitan dengan Karya Ilmiah, yaitu Slamet (2007), Sariono (2013), Lifter dan Tschiener (2013), Syaefullah, A. (2015), Saputra (2016. Teori metode pembelajaran yang digunakan Sudjana (2005), Anderson, (2008), Sutikno (2009, Huda (2011), Hanafiah, N dan Cucu S, (2010), dan Rusman (2010). Teori berkaitan dengan HOTS, yaitu (King, Goodson, \& Rohani, 1998), Lorin Anderson, David Krathwohl, (2001). Selain buku, sumber rujukan dari jurnal juga digunakan dalam penelitian konseptual ini. Jurnal yang dirujuk adalah jurnal nasional dan jurnal internasional. Pembahasan dalam penelitian ini dilakukan secara konseptual, yaitu berdasarkan teori rujukan yang digunakan.

\section{HASIL DAN PEMBAHASAN}

Penerapan pembelajaran berbasis HOTS, yaitu sebagai berikut. (1) guru melakukan orientasi. Pada awal pembelajaran dimulai dengan orientasi. Orientasi dilakukan dengan membawa siswa memikirkan dan menganalisis permasalah yang berkembang di kehidupan saat ini. Masalah-masalah tersebut didiskusikan secara bersama-sama. Pada tahap ini dikembangkan kemampuan menganalisis siswa. (2) merumuskan masalah, pada tahap ini secara pribadi siswa ditugaskan memilih satu masalah. Masalah yang dipilih berdasarkan pada masalah yang telah didiskusikan tadi. Masalah yang telah dipilih dikembangkan dalam bentuk rumusan dan tujuan penelitian. Pada tahap ini juga dikembangkan kemampuan mengevaluasi siswa. (3) merumuskan hipotesis, pada tahap ini siswa dituntun merumuskan jawaban 
sementara dari rumusan masalah yang telah dikembangkan tadi. Guru membimbing siswa menemukan jawaban sementara tersebut. Rumusan jawaban sementara bisa didapat dari literatur yang ada. Pada tahap ini dikembangkan kemampuan menganalisis, mengevaluasi, dan mencipta siswa. (4) mengumpulkan data, setelah merumuskan hipotesis, siswa diajak mengumpulkan data. Pengumpulan data bisa didapat di lapangan dengan cara wawancara, menganalisis atau mengevaluasi dokumentasi yang berkaitan dengan masalah, dan hal lainnya. Selain itu, data juga bisa dikumpulkan dengan melakukan kajian literatur. Pada tahap ini dikembangkan kemampuan menganalisis dan mengevaluasi. (5) menguji hipotesis, setelah data terkumpul siswa ditugaskan melakukan pengujian hipotesis. Pengujian hipotesis dapat dilakukan dengan menganalisis dan menilai data yang telah didapat dari pengumpulan data sebelumnya. Pada tahap ini siswa juga ditugaskan membuat pembahasan berdasarkan data yang telah dianalisis. Pada tahap ini dikembangkan kemampuan menganalisis, mengevaluasi, dan mencipta siswa. (6) merumuskan kesimpulan, pada tahap ini siswa diminta untuk menilai dan mengevaluasi pembahasan yang dilakukan. Setelah itu, menyimpulkan apa yang telah didapat selama proses penulis karya ilmiah. Pada tahap ini, siswa mendiskusikan secara bersama-sama kesimpulan yang telah didapat. Pada tahap ini guru, memberikan penguatan terhadap hasil penelitian yang didapat oleh siswa. Pada saat ini juga, guru menguatkan materi pembelajaran hari ini. Pada tahap ini dikembangkan kemampuan menganalisis dan mengevaluasi.

\section{PENUTUP}

\section{Simpulan}

Pembelajaran berbasis HOTS adalah pembelajaran yang dilakukan dapat menumbuhkan, mengembangkan, dan membangkitkan kemampuan bernalar dan berpikir tingkat tinggi siswa. Kemampuan berpikir tingkat tinggi dimulai dari level 4 sampai level 6, yaitu menganalisis, mengevaluasi, dan mencipta. Metode yang dapat digunakan dalam pembelajaran berbasis HOTS, yaitu pembelajaran berbasis masalah (problem based learning), inkuiri (inquiry), dan penyelidikan kelompok (group investigation). Hasilnya dengan menerapkan pembelajaran HOTS (Higher Order Thinking Skills kemampuan siswa untuk berpikir secara kritis pada sekolah menengah pertama lebih cepat dalam menerima berbagai jenis informasi, berpikir kreatif dalam memecahkan suatu masalah menggunakan pengetahuan yang dimiliki serta membuat keputusan dalam situasi-situasi yang kompleks.

\section{Saran}

Berdasarkan temuan ini disarankan pembelajaran HOTS (Higher Order Thinking Skills selain diterapkan pada sekolah menengah pertama, selanjutnya dapat diterapkan di Sekolah Menengah Atas dan Jenjang Perguruan Tinggi karena dapat meningkatkan hal positif terbentuknya kerjasama di antara siswa dan mahasiswa, interaksi siswa kepada guru dan mahasiswa terhadap dosen meningkat, serta meningkatkan karakter.

\section{DAFTAR PUSTAKA}

Anderson, J. R. (2008). Problem solving and learning. American psychologist. Vol. 48. No. I. 35-4-1.

Anderson, L.W., dan Krathwohl, D.R. (2001). A Taxonomy for learning, teaching, and assesing; A revision of bloom's taxonomy of education objectives. New York: Addison Wesley Lonman Inc.

Apandi, Idris (2017). Pembelajaran dan penilaian HOTS. Bandung: Widyaiswara Lembaga Penjaminan Mutu Pendidikan (LPMP) Jawa Barat. 
Julianda, Utami Widiati, E. T. D. R. (2015). Tingkat berpikir siswa pada mata pelajaran IPS di Sekolah Menengah Pertama.

King, F. J., Goodson, L., \& Rohani, F. (1998). Higher Order Thinking Skills. Publication of the Educational Services Program, Now Known as the Center for Advancement of Learning and Assessment. Obtido de: Www.cala.fsu.edu, 1-176. Retrieved from_http://www.cala.fsu.edu/ files/higher_order_thinking_skills.pdf

Kurnianingsih, Ragil. Iskandar, Srini M,A. D. (2013). Perbedaan Kemampuan Berpikir Tingkat Tinggi dan Pemahaman Konsep Materi Hidrolisis Garam Siswa MA Negeri 2 Malang pada Penerapan model Pembelajaran Inkuiri Terbimbing.

Limbach \& Waugh. (2010). Developing Higher Level Thinking. Journal of Instructional Pedagogies, 1-9.

Nisa, Choerun Nur, Nadiroh, Eko Siswono. (2018). Kemampuan Berpikir Tingkat Tinggi (Hots) Tentang Lingkungan
Berdasarkan Latar Belakang Akademik Siswa. Volume XIX Nomor 2 September 2018 e-ISSN : 2580-9199.114

Nurhaidah, M. Insya Musa. (2015). Dampak Pengaruh Globalisasi Bagi Kehidupan Bangsa Indonesia. Jurnal Pesona Dasar Universitas Syiah Kuala Vol. 3 No. 3, April 2015, hal 1- 14 ISSN: 2337-9227

Prasad, Bhawani. (2012). Higher Order Thinking in Education. Academic Voices A Multidisciplinary Journal Volume 2, N0. 1, 2012.pp 5-10

Sofyan, Fuaddilah Ali. (2019). Implementasi HOTS Pada Kurikulum 2013. Jurnal Inventa Vol III. No 1 Maret 2019:1-17.

Sunaryo,Wowo. (2012). Taksonomi Kognitif. Bandung: Rosda Karya.

The Quality Assurance Agency (QAA), \& The Higher Education Academy (HEA). (2014). Education for Sustainable Development, XXI (June), 26. Retrieved from http://www.qaa. ac.uk/en/Publications/ Documents/ Education-sustainable-developmentGuidance-June-14.pdf 